\title{
Research on the Development Path of Domestic Tourism Characteristic Towns from the Perspective of Integration of Culture and Tourism
}

\author{
Qingsheng Wang, Shihan Liu* \\ School of Management, Tianjin University of Commerce, Tianjin, China \\ Email: wqsheng001@126.com, *1095969906@qq.com
}

How to cite this paper: Wang, Q. S., \& Liu, S. H. (2021). Research on the Development Path of Domestic Tourism Characteristic Towns from the Perspective of Integration of Culture and Tourism. Open Journal of Social Sciences, 9, 234-242. https://doi.org/10.4236/jss.2021.91016

Received: December 23, 2020

Accepted: January 17, 2021

Published: January 20, 2021

Copyright (อ 2021 by author(s) and Scientific Research Publishing Inc. This work is licensed under the Creative Commons Attribution International License (CC BY 4.0).

http://creativecommons.org/licenses/by/4.0/ (c) (i) Open Access

\begin{abstract}
Cultural tourism characteristic towns have become the main competitiveness of small town tourism development. As a carrier to promote the development of urban-rural integration, tourism characteristic towns play an increasingly important role. Cultural tourism characteristic towns have become the main competitiveness of the town's tourism development. With the support of the government, the characteristic towns of cultural tourism have become one of the hotspots of academic circles and industries. By analyzing the relevant literature of tourism characteristic towns, it can be found that the development of characteristic towns in China has obvious stage characteristics. In view of the challenges and significance of the development about cultural tourism characteristic towns at present, this paper puts forward specific countermeasures to realize the sustainable development of cultural tourism characteristic towns in China.
\end{abstract}

\section{Keywords}

Integration of Culture and Tourism, Tourism Characteristic Town, Development

\section{Research Background}

Cultural tourism is a happy industry, which is loved by people, highly participated by the people and reflects people's longing for a better life. With large development space and strong consumption demand, it will become the main force to boost consumption during the $14^{\text {th }}$ Five-Year Plan period. In January 2018, the Opinions of the CPC Central Committee and the State Council on Imple- 
menting the Rural Revitalization Strategy pointed out the significance of comprehensively implementing the rural revitalization strategy, and made scientific planning and deployment. The National Development and Reform Commission pointed out that characteristic towns should be people-oriented, show their characteristics, aggregate elements and refine cultural elements and symbolic symbols. It also encourages qualified scenic spots to build characteristic tourist attractions to transform beautiful resources into "beautiful economy". It can be seen that the construction of characteristic towns should highlight the characteristics of "integration of culture and tourism", and the concept of "promoting tourism with culture, promoting culture with tourism, and coexisting together". Therefore, the construction of characteristic towns with the integration of culture and tourism is an important means to realize the modernization of agriculture and rural areas in the new period. It is an important way of rapid transformation and promotion of rural economy, and it is also a concrete manifestation of the implementation of rural revitalization strategy.

The concept of "characteristic town" was first proposed in October 2014 by Comrade Li Qiang, then governor of Zhejiang Province (Feng, 2016). "Characteristic town" is not the category of "town" in the traditional national administrative division. Instead, through deep excavation, with characteristic industries and industrial culture as the core, and in accordance with the development concept of "innovation, coordination, green, openness and sharing", an industrial upgrading and economic transformation platform with certain characteristic industries, integration of the whole industrial chain with different functions and aggregation of various innovative elements will finally be formed. With the development of tourism entering the whole industrial chain development mode, the former family-style rural tourism mode can no longer adapt to the development of form, and needs to take the intensive development road. Therefore, it is very necessary to integrate rural tourism into the construction of characteristic towns. This is in line with people's psychological needs of "returning to nature", and meets the objective requirements of the transformation of China's tourism development form. It makes the forms of eco-tourism in China more diversified, showing a diversified and characteristic development trend.

\section{Research Status on the Development of Domestic Tourism Characteristic Towns}

\subsection{Research Status of Tourism Characteristic Towns}

Since the characteristic town was put forward in 2014, the government has created the characteristic town, and discussed the characteristic towns in terms of positioning, fulfillment and replenishment. In 2015, building characteristic towns officially entered the implementation stage (Zhang, 2016). Driven by the diversification of tourism demand, towns with tourism characteristics emerged in the process of urban-rural integration, and became an innovative model of small town construction (Zhao, 2017). At present, the development of characteristic 
towns is mainly as follows: firstly, tourism-oriented characteristic towns, followed by industry-oriented characteristic towns (Wang, 2019). Among them, the characteristic towns which mainly focus on cultural tourism account for more than half. It can be seen that during the development of characteristic towns, the government, enterprises and scholars pay more attention to the value of local culture and inheritance embodied in tourist characteristic towns (Xie \& Hua, 2019). As an important factor for the sustainable development of characteristic tourist towns, the tourism characteristic town model in the form of integration of culture and tourism has been widely recognized by the public (Meng \& Zhao, 2020; Fan, 2020). Relying on CNKI, the full-text database of Chinese academic journals, as of the end of December, 2020, a total of 1790 qualified domestic literatures were preliminarily retrieved under the title of "Tourism Characteristic Towns". Only from the quantitative analysis of the literature (as shown in Figure 1), since it was first proposed in 2014, the research on tourism characteristic towns has experienced a process from scratch. In addition, research on tourism in characteristic towns has become increasingly popular in China since 2015, with a total of 534 papers by 2020. This shows that tourism in characteristic towns is getting more and more attention from the public. It has become an important research field in domestic academic circles. Under the background of rapid economic and social development in China, this trend is closely related to the widening of domestic tourism development field and the gradual active tourism market of domestic characteristic towns.

\subsection{Development Status of Tourism Characteristic Towns}

There are three types of geographical location characteristics of towns with Chinese characteristics: suburbs of big cities, outer suburbs of big cities and agricultural areas. The characteristic towns in agricultural areas are the most, followed by the suburbs of big cities, while the characteristic towns in the outer suburbs of

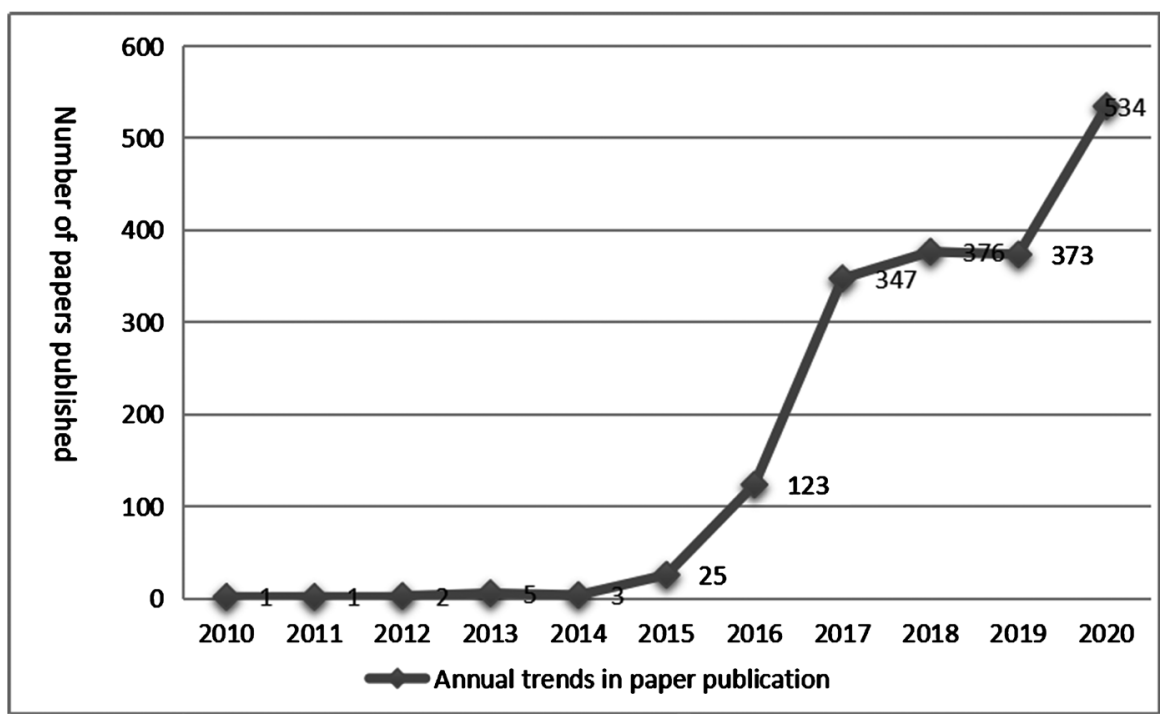

Figure 1. The number of documents in tourist towns at the end of 2010-2020. 
big cities are the least. From the north-south distribution, there are more characteristic towns in the suburbs of big cities in the south than in the north, while there are more agricultural towns in the north than in the south. On October 14, 2016, the Ministry of Housing and Urban-Rural Development officially announced 127 towns with Chinese characteristics, including Changgou Town, Fangshan District, Beijing, and 276 towns, including Yanqi Town, Huairou District, Beijing, as the second batch of towns with Chinese characteristics in August 2017. In terms of the number of characteristic towns in each province, Zhejiang has the largest number of 23, while the rest of Jiangsu, Shandong, Sichuan and Guangdong have all reached 20. But on the whole, it does not show obvious regularity.

By 2019, there were 403 characteristic small towns and 996 provincial characteristic towns in China. In terms of the types of characteristic towns, there are mainly six types, namely, industrial development type, historical and cultural type, tourism development type, ethnic settlement type, agricultural service type and commercial circulation type. Among them, the number of characteristic towns with tourism development type is the largest, 144, accounting for $35.7 \%$. According to the distribution of characteristic towns in provinces and cities shown in Figure 2, most of them are coastal provinces and cities. Among them, Zhejiang Province has the largest distribution number of 23, followed by Jiangsu Province and Shandong Province, with both with 22. At present, the characteristic town industry has become a new driving force for China's current economic development. And at the $19^{\text {th }}$ Congress of the Communist Party of China, it was proposed that the major strategic measure to implement the rural revitalization strategy is to build characteristic towns. In the long run, the smooth promotion of the strategy of characteristic towns has important thrust on rural revitalization, industrial layout and urban-rural integration. The popularity of cultural tourism Town continues. Cultural tourism town, which integrates many functions such as industry, culture, tourism and community, has been one of the

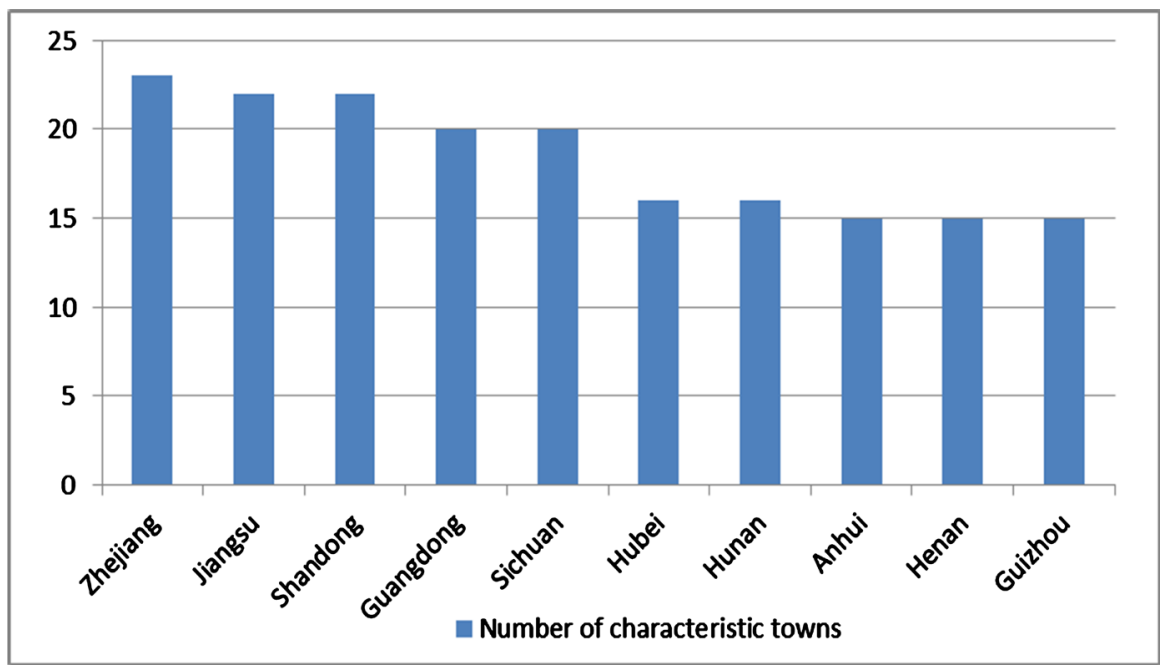

Figure 2. Number of characteristic towns in China by the end of 2019. 
hotspots in the development of characteristic towns in the past few years. And this heat will continue in the new year. Tourism has developed from a traditional and single sightseeing tour to a tour with various forms, rich contents and remarkable characteristics. The development of towns with cultural and tourism characteristics will also cater to consumers' preferences, it will provide detailed, customized and personalized tourism products to attract more tourists.

\subsection{Challenges Faced by the Development of Tourism Characteristic Towns}

The first challenge is the changeable tourism market pattern in the post-epidemic era. In 2020, the pneumonia epidemic in COVID-19 broke out all over the world. The diversified tourism market pattern before the epidemic has been significantly reduced after the epidemic.

The domestic epidemic prevention and control has achieved significant phased victory, and entered the period of normalization of epidemic prevention and control. In terms of inbound tourism market, the market scale will be drastically reduced in the future due to repeated foreign epidemics and restrictions on international navigation. In the domestic tourism market, inter-provincial tourism will gradually make up the gap of international tourism, the domestic tourism market scale is expected to increase. However, in the post-epidemic era, domestic long-distance travel will be impacted to varying degrees due to the requirements of epidemic prevention and control, especially the characteristic town tourism, which is a gathering and intensive tourist destination.

The second challenge is that the contradiction between the supply and demand of cultural and tourism products is prominent. In recent years, tourism in the province, surrounding tourism and rural tourism have been increasingly favored by people. Short-distance tourism has gradually integrated into people's lives and developed into a way of life. Skilled tourism began to appear and developed rapidly. On the other hand, the COVID-19 epidemic of 2020 has changed people's way of life and work, the boundary between leisure and work will gradually blur. Tourists' pursuit of mobility will change their way of life and work, resulting in new phenomena such as "family vacation", "work vacation" and "vacation work". Faced with new demands, the current tourism products of characteristic towns are obviously unable to meet. Although introducing new products through the integration of culture and tourism can effectively solve this contradiction, how to integrate them is still being explored.

The third challenge is the lack of innovative design and flexible operation mechanism in the tourism characteristic towns with the integration mode of culture and tourism. The design of cultural landscape activities in tourist characteristic towns still stays in the "cursory" viewing mode, lacking the interactive activities with tourists as the main body, the tourists' experience is not high, and the cultural connotation of tourist towns is not well understood, which affects the establishment of cultural tourism brands in small towns. At present, the design 
mode of tourism characteristic town is single, which does not reflect the particularity of local culture and has strong substitutability. The operation mechanism is not sound and flexible, and the excessive pursuit of commercialization leads to the distortion of traditional culture characteristic tourism towns.

\section{The Practical Significance of the Integration of Culture and Tourism in the Development of Tourism-Featured Towns}

\subsection{Culture Endows Richer Connotations to Traditional Tourist Towns}

From the perspective of spiritual and social value, firstly, the integration of culture and tourism will help the towns with tourism characteristics to form more diversified cultural and creative products and tourism products with the basis of tourist market. On one hand, the abstract culture is considerable and sensible through concrete and market-oriented products, which promotes the landing and dissemination of culture. On the other hand, it also endows the cultural industry with a more diversified income structure. Thereby creating an endogenous economic foundation for the protection and inheritance of culture. Secondly, incorporating cultural elements into the tourism activities of characteristic towns can increase the sense of experience in the tourism process, enhance the attractiveness of tourism products, enhance the texture and brand value of destination tourism brands, make the tourism itself richer in cultural sense and irreplaceable characteristics, and shape the core competitiveness of destinations. Thirdly, culture is the value upgrade of superstructure and the value promotion of ideology. It plays an important role in promoting the overall value of tourism characteristic town activities by displaying in the form of mass tourism consumption.

\subsection{The Integration of Culture and Tourism Can Effectively Promote the Realization of Tourist Towns' Comprehensive Benefits}

From the perspective of economic value creation, as a new kinetic energy of industrial development, cultural value can bring quadruple value to the development of tourism industry. First, the new business formats, new models, new products, new technologies, new media and new IP produced by the integration of culture and tourism can extend and enrich the respective industrial chains of culture and tourism, and form the coordinated development of multi-industries, industries and enterprises driven by government, industry and enterprises. Secondly, the tourism industry drives the gathering of food, housing, transportation, tourism, shopping, entertainment and other industries, which can increase the employment of tourist destinations. And it can provide a large number of low-cost innovation and entrepreneurship platforms. Thereby effectively relieving the employment pressure of the characteristic town destinations. Thirdly, 
integrating cultural elements into the tourism process of characteristic towns can prolong and expand the tourism consumption chain and gather popularity. Through rich and diverse town tourism and cultural derivatives, the profitability of local tourism enterprises will be enhanced, and the sound development of enterprises will be promoted. Fourthly, the integrated development of culture and tourism can increase the economic aggregate of characteristic town destinations and enhance the overall development level of social economy.

\section{Development Path and Countermeasures of Tourism Characteristic Towns with Integration of Culture and Tourism}

\subsection{Promote the Industrial Integration and Development of Tourism Characteristic Towns with the Strategy of "Cultural Tourism+"}

Comprehensively promote the strategy of "cultural tourism+", accelerate the integration and development of cultural and tourism industries with other small town industries, innovate the development model, and form "cultural + tourism + characteristic towns", "cultural tourism characteristic towns + agriculture", "cultural tourism characteristic towns + industry", "cultural tourism characteristic towns + education", "cultural tourism characteristic towns + health care", "cultural tourism characteristic towns+ sports", "Cultural tourism characteristic town + information technology" etc. new global tourism formats at the industrial level. Support the continuous expansion of tourism elements, continue to adhere to and gradually deepen the tourism characteristic towns around the promotion of cultural tourism, the recreation and sports integration of cultural tourism features of the town to enhance efficiency, the information service of cultural tourism characteristic towns, the financial support for the development of cultural tourism characteristic towns, and the ecological protection for cultural tourism characteristic towns to continue.

\subsection{Further Strengthen the Construction of Cultural Tourism Town Facilities and Improve the Level of Public Cultural Services}

After the outbreak of COVID-19, the tourist towns suffered heavy losses, and the problem of public service level became prominent. Therefore, it is necessary to strengthen the construction of public service facilities in tourist towns and provide humanized, personalized, refined and intelligent tourism services. Improve the passenger transportation system, connecting airports, stations, docks, important transportation hubs and major scenic spots in the city, improve the tourism transportation connection system. Create a "fast trip and slow travel" tourism transportation system, improve aviation, railway, highway, greenway and other transportation networks, strengthen the construction of scenic parking lots, and improve the level of tourism transportation service guarantee. 


\subsection{Introduce Characteristic Products of Cultural Tourism Characteristic Town, Create Boutique Routes}

Starting from the customer's perspective, the tourism town products combined with local cultural characteristics are launched. Increase experiential tourism development mode, activate local characteristic culture, and launch boutique tourism routes. Relying on superior resources such as natural scenery and tourism resources, the resources needed by the target customers will be promoted to the target customers in a way that they like. Construct a comprehensive marketing system matching "target customers-cultural tourism town resources-marketing communication methods".

\section{Conclusion}

Since it was proposed, the town with tourism characteristics has received strong support from the state and attracted wide attention from the academic circle and industry. It will develop rapidly in the future. However, there are some problems in the development process, especially after the outbreak of COVID-19, the tourism market has been tightened, and the foreign tourism market has been almost stopped. Brigade after the outbreak of contradiction between supply and demand is more prominent, distinctive characteristics of small town in the public service, the characteristics of innovation, operating mechanism and so on shortcomings, need through the text brigade fusion model to explore new development path, improve the level of local public service culture tourist town, highlight the characteristics of the local tourist town, to promote the sustainable development of characteristic town integrating culture and tourism.

At the same time, this paper is deficient in the research content. From the research progress and development status quo of tourism characteristic towns, the research content is not comprehensive enough, the coverage is not extensive enough, and the research method is single.

\section{Conflicts of Interest}

The authors declare no conflicts of interest regarding the publication of this paper.

\section{References}

Fan, Y. G. (2020). Cultural Code for Sustainable Development of Characteristic Towns. Academic Exchange, 1, 140-153.

Feng, B. (2016). Characteristic Town: The Great Strategy of Economic Transformation and Upgrading in Zhejiang. Social Sciences of Zhejiang, 3, 39-42.

Meng, N., \& Zhao, F. Q. (2020). Research on the Application of Cultural Tourism IP in the Operation of IP Culture in Featured Towns. Agricultural Economic Issues, 6, 144.

Wang, D. (2019). Cultural Integration of Town Construction with Chinese Characteristics. Journal of South China Normal University (Social Science Edition), 1, 16-19+189.

Xie, J., \& Hua, C. (2019). The Creation of Cultural Tourism Industry in Characteristic Towns. Social Sciences of Jiangxi, 39, 222-227. 
Zhang, W. W. (2016). Government and Creating Characteristic Towns: Positioning, Fulfillment and Replenishment. Social Sciences of Zhejiang, 3, 43-45.

Zhao, H. (2017). The Innovation and Development of Tourism Characteristic Towns. Economic Problem, 12, 104-107. 